Our Nature (2005)3:63-68

\title{
Comparative Analysis of the Flora of Morang District and Adjoining Areas of Nepal
}

\author{
S. Jha \\ Department of Botany, P.G. Campus, Tribhuvan University, Biratnagar, Nepal
}

\begin{abstract}
Nine hundred and forty seven species of vascular plants under 661 genera and 172 families were recorded from Morang district and adjoining areas of Nepal. The genus-species ratio of the vascular plants in general and angiosperms in particular was 1:1.43 and 1:1.44, respectively; and 498 genera of vascular plants were represented by a single species only. On the basis of number of species, Polypodiaceae (11) was the largest family of pteridophytes, and Pinaceae (3) of gymnosperms. Among the angiosperms ten largest families were: Leguminosae $(91)>$ Poaceae $(80)>$ Asteraceae $(57)>$ Euphorbiaceae $(31)>$ Cyperaceae $(28)>$ Rubiaceae $(26)>$ Lamiaceae and Solanaceae $(22$ each) $>$ Acanthaceae $(21)>$ Orchidaceae (20) > Convolvulaceae (16). The biological spectrum of the study area was phanerotherophytic type.

Key words: Conservation, Exotic weeds, Floristic analysis, Life forms, Reproductive seasons
\end{abstract}

\section{Introduction}

Situated between latitudes $26^{\circ} 20^{\prime}$ to $27^{\circ} 10^{\prime} \mathrm{N}$ and longitudes $87^{\circ}$ to $87^{\circ} 30 \mathrm{E}$, the study site is one of the populous areas of Nepal, the population density per sq $\mathrm{km}$ being 288 in 1981, 361 in 1991 and 453 in 2001. Physiographically the study site is divisible into three zones from south to north: (a) the Teraia part of the Indo-Gangetic plain with elevation variations between 60 and 300 $\mathrm{m}$, (b) the Bhabar zone with ele-vation variations between 150 to $700 \mathrm{~m}$ and (c) Mahabharat or mountain ranges with elevation variations between 700 to $2409 \mathrm{~m}$. Nearly $81 \%$ of the total land of the study site is in Terai, $10 \%$ in Bhabar and $9 \%$ in mountain zone. Most of the lower altitude areas are under arable farming. In general, the study site has tropical and monsoonic type of climate with $1312 \mathrm{~mm}$ average annual rainfall, and $30.6^{\circ} \mathrm{C}$ and $14.2^{\circ} \mathrm{C}$ average annual maximum and minimum temperatures, respectively.

Forests of the Terai and Bhabar zones are dominated by Shorea robusta in association with Adina cordifolia, Cassia fistula, Cedrela toona, Dillenia pentagyna, Lagerstroemia parviflora, Mallotus philippensis, Phyllanthus emblica, Schleichera oleosa, Semecarpus anacardium and Terminalia alata. The Terai riverine forest on new alluvial deposits is dominated by Acacia catechu-Dalbergia sissoo association in which Ficus semicordata and Zigiphus mauritiana have fair presence. On the other hand, riverine forest on old alluvial deposits is mainly com-posed of Acacia catechu, Adina cordifolia, Aegle marmelos, Salmalia malabarica, Syzy-gium cumini, Terminalia alata, Trewia nudi-flora, etc. Species composition of the forest of mountain zone consists mainly of Alnus nepalensis, Castanopsis indica, Pinus rox- 
burghii, Pyrus pashia, Rhododendron arboreum, Salmalia malabarica, Schima wallichiii, etc.

This analytical study is based on the floristic expeditions of eight selected locations of the study site made during 1996 to 1998 .

\section{Materials and Methods}

Three locations from Terai (Budhanagar 60 $\mathrm{m}$, Biratnagar $72 \mathrm{~m}$, Koshi Tappu $78 \mathrm{~m}$ ), three locations from Bhabar (Belbari $150 \mathrm{~m}$, Letang $241 \mathrm{~m}$, Kerabari $457 \mathrm{~m}$ ) and two locations from mountain zone (Singhdevisombare $1800 \mathrm{~m}$, Tinjure $2200 \mathrm{~m}$ ) were selected for the floristic expeditions. Among these Budhanagar, Biratnagar, Letang and Singhdevisombare were agricultural areas; Koshi Tappu was a protected wetland; and Belbari, Kerabari and Tinjure were forested areas. All the selected locations except Tinjure (Terhathum district) and Koshi Tappu (Sunsari district) belonged to Morang district. The reason for the selection of Tinjure was that the highest peak of Morang district in the Mahabharat ranges, the 'Mikjani' mountain $(2409 \mathrm{~m})$ was difficult to access and Tinjure was the nearest location to represent Mikjani whereas Koshi Tappu was selected as a representative of the protected Terai marshland.

Plant materials and field data were gathered by making regular visits to the selected locations for three consecutive years. The identified specimens of vascular plants were deposited in the Herbarium of Central Department of Botany (TUCH), Tribhuvan University, Kirtipur, Kathmandu.

\section{Results and Discussion}

In total 947 species of vascular plants (tropical and subtropical 79.5\%, temperate $20.5 \%$ ) were recorded from the study site
(Table 1) in which pteridophytes were represented by 23 families, 44 genera and 61 species; gymnosperms by 5 families, 6 genera and 7 species; and angiosperms by 144 families, 611 genera and 879 species.

Table 2 summarizes the number and percentage of the families, genera and species of dicots and monocots found within the study site. The ratio of the monocot to dicot families was 1:4.76; of genera 1:3.52 and of species 1:3.48. The genus-species ratio of angiosperms was 1:1.44 which was comparatively lower than 1:7 for British India (Hooker, 1872-1897), of 1:6 for India (Kumar and Krishnamurthy, 1992), 1:3.48 for Nepal (Press et al., 2000), and 1:2.2 for the upper Gangetic plains (Duthie, 1903-1929). It indicates that the smaller the area the lower is the genus-species ratio.

In general, as many as 79 families of the vascular plants were represented by a single genus each and 60 families by single species each. Out of the total 661 genera of the study area, 498 were represented by a single species only (Jha and Jha, 2000; Jha, 2003). This finding was in agreement with Hooker's (1904) observation for the plains of the northern Indian subcontinent regarding the preponderance of genera with one species only.

The genera represented by five or more species in the study area were Pteris and Selaginella (5 species each) among the pteridophytes; Cyperus (14) and Carex (5) among the monocots; and Ipomoea (9), Ficus (8), Solanum (8), Persicaria (7), Vigna (7), Acacia (6), Cassia (6), Euphorbia (6), Amaranthus (5) and Crotalaria (5) among the dicots. Some of these genera were also dominant flora of plains of eastern Nepal in terms of number of species (Siwakoti and Varma, 1999).

The relative importance of families in a 


\section{S. Jha / Our Nature (2005)3:63-68}

flora is usually expressed by tabulating the largest ten families in the order of their number of species and comparing it with those of the adjacent regions. Table 3 , thus, depicts the ten dominant families in Morang district and adjoining areas, the Terai plains of Nepal, whole Nepal, British India and the entire world. It is interesting to note that the Leguminosae, Asteraceae, Poaceae and Cyperaceae are the most dominant families in all the regions irrespective of their spatial size. According to Good (1953), almost everywhere Leguminosae, Asteraceae, Poaceae and Cyperaceae are among the first six, but thereafter much depends on whether the area concerned is temperate, in which case families such as Caryophyllaceae, Brassicaceae, Ranunculaceae, Rosaceae and Scrophulariaceae rank high; or whether it is tropical, in which case families such as Acanthaceae, Euphorbiaceae, Rubiaceae, Lamiaceae and Solanaceae take their place. The predominant tropical families such as Euphorbiaceae, Rubiaceae, Lamiaceae, Solanaceae and Acanthaceae were among the ten largest families in Morang district and adjoining areas of Nepal (Table 3).

The statistical analysis of basic life-forms (habits) indicated the predominance of herbs followed by shrubs and trees in the study area (Table 4) which was mainly due to increase in human population, settlements and townships, modification or destruction of habitats, increase in area under arable farming, overgrazing, and roads and industries. In this context plant species deserving immediate conservation efforts due to their suitability in restoring the degraded ecosystems and their high potentials in fostering the rural cottage industries (edible fruits/vegetables/potherbs, feed for livestock, medicines, fuels, agricultural and household implements, thatch, mats, basketry, bee-keeping, sericulture etc.) were: Acacia catechu (Leguminosae), Adina cordifolia (Rubiaceae), Aegle marmelos (Rutaceae), Aesandra butyracea (Sapotaceae), Alstonia scholaris (Apocynaceae), Borassus flabellifer and Calamus tenuis (Arecaceae), Cassine glauca (Celastraceae), Cyathea spinulosa (Cyatheaceae / pteridophyta), Dillenia pentagyna (Dilleniaceae), Ehretia laevis (Cordiaceae), Glochidion lanceolarium (Euphorbiaceae), Grewia subinaequalis (Tiliaceae), Holarrhena pubescens (Apocynaceae), Hymenodictyon

Table 1. Floristic analysis of the explored vascular plants

\begin{tabular}{lccc}
\hline Plant Group & Families & Genera & Species \\
\hline Pteridophytes & 23 & 44 & 61 \\
Gymnosperms & 5 & 6 & 7 \\
Monocots & 25 & 135 & 196 \\
Dicots & 119 & 476 & 683 \\
Total & $\mathbf{1 7 2}$ & $\mathbf{6 6 1}$ & $\mathbf{9 4 7}$ \\
\hline
\end{tabular}


S. Jha / Our Nature (2005)3:63-68

Table 2. Percentage and ratios of families, genera and species of monocots and dicots

\begin{tabular}{lccccccc}
\hline \multirow{2}{*}{ Taxa } & \multicolumn{2}{c}{ Dicots } & \multicolumn{2}{c}{ Monocots } & \multirow{2}{*}{ Total } & \multicolumn{2}{c}{ Ratio } \\
\cline { 2 - 5 } & Total number & \% & Total number & \% & & Monocots:Dicots \\
\hline Families & 119 & 82.64 & 25 & 17.36 & 144 & 1 & 4.76 \\
Genera & 476 & 77.91 & 135 & 22.09 & 611 & 1 & 3.52 \\
Species & 683 & 77.70 & 196 & 22.30 & 879 & 1 & 3.48 \\
\hline
\end{tabular}

Table 3. Representation of dominant families in various floras in the order of decreasing members

\begin{tabular}{lllll}
\hline MDAA & TPN & NEP & BI & WF \\
\hline Leguminosae & Poaceae & Aseraceae & Orchidaceae & Asteraceae \\
Poaceae & Leguminosae & Poaceae & Leguminosae & Poaceae \\
Asteraceae & Asteraceae & Orchidaceae & Poaceae & Orchidaceae \\
Euphorbiaceae & Cyperaceae & Leguminosae & Rubiaceae & Leguminosae \\
Cyperaceae & Euphorbiaceae & Rosaceae & Euphobiaceae & Euphorbiaceae \\
Rubiaceae & Rubiaceae & Cyperaceae & Acanthaceae & Rubiaceae \\
Lamiaceae/Solanaceae & Acanthaceae & Scrophulariaceae & Asteraceae & Arecaceae \\
Acanthaceae & Convolvulaceae & Ranunculaceae & Cyperaceae & Liliaceae/Melastomataceae \\
Orchidoceae & Scrophulariaceae & Lamiaceae & Lamiaceae & Cyperaceae/Lamiaceae/Rosaceae \\
Convolvulaceae & Lamiaceae & Rubiaceae & Urticaceae & Myrtaceae/Scrophulariaceae \\
\hline
\end{tabular}

MDAA = Morang distict and adjoing areas; TPN = Terai plains of Nepal (Siwakoti and Varma, 1999); NEP = Nepal (Hara et al., 1978-1982); BI = British India (Hooker, 1904); WF = World Flora (Lawrence, 1965).

Table 4. Basic life form (habit) of the recorded vascular plants

\begin{tabular}{lcc}
\hline Life form & Number of species & Percentage Contribution \\
\hline Trees & 141 & 14.9 \\
Shrubs & 142 & 15.0 \\
Undershrubs & 42 & 4.4 \\
Woody Climbers & 34 & 3.6 \\
Herbaceous climbers & 55 & 5.9 \\
Herbs & 460 & 48.6 \\
Hydrophytes & 38 & 4.0 \\
Epiphytes & 32 & 3.3 \\
Parasites & 3 & 0.3 \\
Total & 947 & 100.0 \\
\hline
\end{tabular}

Table 5. Raunkiaer's life forms in Morang district and adjoining areas*

\begin{tabular}{ccc}
\hline Life forms & Number of species & Percentage \\
\hline P & 330 & 34.9 \\
C & 139 & 14.7 \\
H & 61 & 6.4 \\
G & 134 & 14.2 \\
T & 282 & 29.8 \\
\hline
\end{tabular}

*P $=$ Phanerophytes (perennating buds more than $0.3 \mathrm{~m}$ above ground) $\mathrm{C}=$ Chamaephytes (perennating buds up to $0.3 \mathrm{~m}$ above ground); $\mathrm{H}=$ Hemicryptophytes (perennating buds close to the ground/ nearly half hidden in the soil); $\mathrm{G}=$ Geophytes (perennating buds underground); $\mathrm{T}=$ Therophytes (annuals). 


\section{S. Jha / Our Nature (2005)3:63-68}

excelsum (Rubiaceae), Lagerstroemia plant reproduction and reciprocally for food for parviflora (Lythraceae), Litsea monopetala the animals involved (Frankie et al., 1974). (Lauraceae), Madhuca longifolia (Sapotaceae), Observations made on the recorded plants in Mallotus philippensis (Euphorbiaceae), the study area revealed that 50\% species Mitragyna parviflora (Rubiaceae), Nelumbo attained the reproductive phase during nucifera and Nymphaea stellata September-November, $22 \%$ in December(Nymphaeaceae), Oroxylum indicum February, and 23\% in March-August whereas flowering and fruiting occurred throughout the

(Bignoniaceae), Pandanus nepalensis (Pandanaceae), Paris polyphilla (Liliaceae), Phoenix sylvestries (Arecaceae), Phyllanthus emblica (Euphorbiaceae), Piper longum (Piperaceae), Rauvolfia serpentina (Apocynaceae), Salix tetrasperma (Salicaceae), Salmalia malabarica (Bombacaceae), Schleichera oleosa (Sapindaceae), Semecarpus anacardium (Anacardiaceae), Shorea robusta (Diperocarpaceae), Spondias pinnata (Anacardiaceae), Sterculia villosa (Sterculiaceae), Syzygium cumini (Myrtaceae), Tamarindus indica (Leguminosae), Taxus baccata (Taxaceae/ gymnosperm), Terminalia bellirica and $T$. chebula (Combretaceae), Trewia nudiflora (Euphorbiaceae), Uvaria hamiltonii (Annonaceae), Vetiveria zizanioides (Poaceae) and Ziziphus mauritiana (Rhamnaceae).

The study of Raunkiaer's (1934) life forms showed predominance of phanerophytes (34.9\%) followed by therophytes (29.8\%) (Table 5). Thus biological spectrum of the study area was phanero-therophytic type. The phanerophytes are the plants of warm and moist climate and therophytes of warm and dry climate. The climate of Morang district and adjoining areas in general is warm and dry during summer and warm and moist during the rainy season. This explains the preponderance of phanerophytes and therophytes in the study area.

Phenological information can also be used to study animal-plant interactions which affect pollination, seed dispersal, and fruit/seed predation. These interactions are important for year in only $5 \%$ species.

Some of the notable exotic weed species of the study area were Alternanthera paronychioides, A. philoxeroides, Chromolaena odorata, Eichhorrnia crassipes, Eupatorioum adenophorum, Gomphrena celosioides, Ipomoea carnea, Lantana camara, Mecardonia procumbens, Mikania micrantha, Parthenium hysterophorus, Peperomia pellucida, Solanum aculeatissimum and Tridax procumbens. Among These $C$. odorata, E. adenophorum, $L$. camara and $M$. micrantha were most obnoxious in forests; A. philoxeriodes, E. crassipes and $I$. carnea in wetlands; and $P$. hysterophorus in grazing fields, road-sides etc.

Some of the taxa of the study area not included in any of the standard publications on the flora of Nepal (Hara et al., 1978-1982; Iwatsuki, 1988; Siwakoti and Varma, 1999; Press et al., 2000; HMG, 2001) were Stenochlaena palustre L. (Lomariopsidaceae) among the pteridophytes and Borassus flabellifer L. (Arecaceae), Cassine paniculata (Wight \& Arn.) Raman (Celastraceae), Ceratophyllum demersum L. (Cerato-phyllaceae), Corchorus urticifolius Wight \& Arn. (Tiliaceae), Dysophylla cruciata Benth. (Lamiaceae), Nymphaea pubescens Willd. (Nymphaeaceae), Ocimum sanctum L. (Lamiaceae), Opuntia elatior Mill (Cactaceae), Prosopis cineraria L. (Leguminosae) and Sclerostachya fusca(Roxb.) A. Camus (Poac-eae) among the angiosperms.

\section{Acknowledgement}

Author is grateful to Prof. Dr. P.K. Jha, Head, 


\section{S. Jha / Our Nature (2005)3:63-68}

Central Department of Botany, Tribhuvan University, Kirtipur, Kathmandu for facilities and encouragements.

\section{References}

Duthie, J.F 1903-1929. Flora of Upper Gangetic Plain and the adjacent Siwalik and Sub-Himalayan Tracts, 3 volumes, Calcutta.

Frankie, G.W., G. Baker and P.A. Opler 1974. Tropical plant phenology: applications for studies in community ecology. In: Phenology and Seasonality Modeling (Ed. H. Lieth). SpringerVerlag, Berlin-Heidelberg-New York. pp. 287296.

Good, R. 1953. The Geography of Flowering Plants. Longmans, London.

Hara, H. and L.H.J. Williams (Eds.) 1979. An Enumeration of the Flowering Plants of Nepal, Vol. 2. British Museum (Natural History)Publ. 810: 1220.

Hara, H., A.O. Chater and L.H.J.Williams (Eds.) 1982. An Enumeration of the Flowering Plants of Nepal, Vol. 3. British Museum (Natural History) Publ. 854: $1-226$.

Hara, H., W.T. Stearn and L.H.J. Williams (Eds.) 1978. An Enumeration of Flowering Plants of Nepal, Vol. 1. British Museum (Natural History) Publ. 777: 1-154.

HMG (His Majesty's Government, Nepal) 2001. Flowering Plants of Nepal (Phanerogams).
Department of Plant Resources, Lalitpur.

Hooker, J.D. 1904. A Sketch of the Flora of British India. Eyre and Srottiswoode, London.

Iwatsuki, K. 1988. An enumeration of the pteridophytes of Nepal. In: The Himalayan Plants, Vol. 1. (Eds. H. Ohba and S.B. Malla) University of Tokyo, Tokyo. pp. 231-339.

Jha, S. 2003. Ecological study of some selected grasses and forbs found in Morang district of Nepal. Tribhuvan University, Kathmandu. (Ph.D. Thesis)

Jha, S. and P.K. Jha 2000. Contributions to the flora of Morang district and adjoining areas of Nepal. Lidia (A Norwegian Journal of Botany) 5(1-2): 2564.

Kumar, T.S. and K.U. Krishnamurthy. 1992. Comparative analysis of the flora of Shervaroy Hills of Eastern Ghats. Geobios new reports 11 : 31-38.

Lawrence, G.H.M. 1965. Taxonomy of Vascular Plants. Macmillan Co., New York.

Press, J.R., K.K. Shrestha and D.A.Sutton 2000 Annotated Checklist of the Flowering Plants of Nepal. The Natural History Museum, London .

Raunkiaer, C. 1934. The life form of Plants and Statistical Plant Geography. Clarendon Press, Oxford.

Siwakoti, M. and S.K. Varma 1999. Plant Diversity of Eatern Nepal. Bishen Singh Mahendra Pal Singh, Dehra Dun, India. 